\title{
The Analysis of Self-Concept Scale in Engineering Faculty: A Rasch Model Analysis
}

\author{
Jahju Hartanti* \\ Guidance and Counseling Program \\ Faculty of Education \\ Universitas PGRI Adi Buana \\ Surabaya, East Java-Indonesia \\ jahjuhartanti789@gmail.com*
}

\author{
Lucky Nindi R. Marfu'i \\ Guidance and Counseling Program \\ Education and Social Science Faculty \\ Universitas Indraprasta PGRI \\ East Jakarta, Indonesia \\ riandika.lucky29@gmail.com
}

\begin{abstract}
Self-concept is a way of how we perceive ourselves in terms of physical or individual's characteristics regarding the strengths and the weaknesses. Self-concept needs to be measured by an instrument that needs to be identified the reliability to measure the college student's self-concept. Engineering students are often faced with practical lectures and rarely have a dominant social world because of their daily activities are often spent to interacting with lab tools and materials. This article is going to discuss about the result of instrument's item analysis in the form of self-concept scale given to the engineering faculty college students. The analysis includes; difficulty level analysis, item distribution, instrument's consistency, consistency of the item on measuring self-concept, consistency of the engineering students in answering the items, and overall reliability using RASCH analysis model. This is conducted to evaluate the existing self-concept scale, so that the instrument's performance can be developed. Method used in this research is literature study and quantitative descriptive. In this method, evaluation and instrument identification in the form of developed selfconcept scale has been conducted. The self-concept scale used has reliability in the moderate category, consistency of student's in answering and item's reliability is in high category, the average engineering student answered the question below the question's difficulty level. It can be concluded that average items in self-concept scale is difficult to be comprehend by students and less able to measure student's self-concept and the difficulty level need to be simplified. This can be performed by re-testing the instruments to the same students to test the reliability through test-retest.
\end{abstract}

Keywords-self-concept, engineering faculty, adolescent, RASCH Model Analysis

\section{INTRODUCTION}

Students in engineering faculty known as active and creative students in practicum fields with machines and often work in the fields. This fact makes engineering students considered less socializing with world of friendship and known as tactical in solving personal problems. Self-concept is part of the self-adjustment and self-esteem [1]. Moreover, self-concept is the result of social interaction in the environment [2]. Based on that statement, engineering student's self-concept according to their socialization result during in the university need to be identified to recognize their ability to adapt in their social environment as well.
Self-concept is a variable related to self-esteem. However, self-concept and self-esteem are separate factors with unique associations for self-adjustment numbers in respondents. Self-concept is part of the realm of affection or feeling which is the determinant of the value of behavior and individual psychological adjustment [1] Self-concept influences the development of individual interests and decision making [2] Self-concept refers to one's thinking in evaluating himself and giving an assessment of himself.

Self-hatred, self-neglect, and self-blame include negative self-concept [3] Self-concept will affect individual academic achievement, when a teenager has a high selfconcept, he will have good academic achievement [4,5] Good achievements will lead to a good career too. A good career will provide a positive self-image so that the individual will be more highly actualized.

The self-concept of adolescents is not affected by age and gender. Antisocial adolescents have negative and autonomous self-concepts. Teenagers who are autonomous means that women have hatred compared to other groups. The results showed that normal adolescents will have a selfconcept that is not chaotic, so negative self-concept is only possessed by adolescents who have an antisocial lifestyle [6]. Students who get special treatment in inclusive schools will reduce the student's self-concept. In regular classroom conditioning in learning it is necessary to apply social interaction that develops students 'self-concepts and does not cause mild interference with students' self-concept [7].

Self-concept is individual's self-image, whether in form of physical, social, or psychological that becomes expectation of their self in the future and will form interactions with their environment and personal experience [8] This statement explains that the primacy of self-concept in daily life determines the future. If the students in engineering faculty often practice with tools or innanimate objects such as machines, etc. How will their self-concept going to be?

This become a big question in social science. It is actually not easy to make judgement on a problem with only common sense, but in this study, one if the goal is to measure the ability of engineering faculty college student's self- concept variable. In addition, in this article will be described the evaluation result of self-concept scale that the researcher used to measure the self-concept of engineering $s$ 
Based on picture above, the question that have the highest difficulty level is the question number 50, 20, 24 , up to number 52. Whereas the question that include as the easy question to answer is question number 31 , 01,32 , up to number 41 . On figure 2 , there is a has sign (in the blue box) to reflect the position of the respondent on answering self-concept scale item constructed by Elisa [11].

In that box, the hash sign are not parallel with the item's distribution, so it can be concluded that the self- concept scale items still cannot be used to measure engineering faculty college student's selfconcept. In other words, this instrument still has a low measuring performance category when applied to engineering faculty college students in UNIPA. This can also prove that when this instrument applied to the engineering faculty student is not appropriate, therefore, it needs further testing with different subject groups to identify the usefulness of the self-concept scale developed by Elisa.

\section{The Analysis of Students Ability}

The next data analysis aims to identify the respondent's ability through self-concept score tha thas been achieved, through the figure of the answer's consistency from the following skalogram.

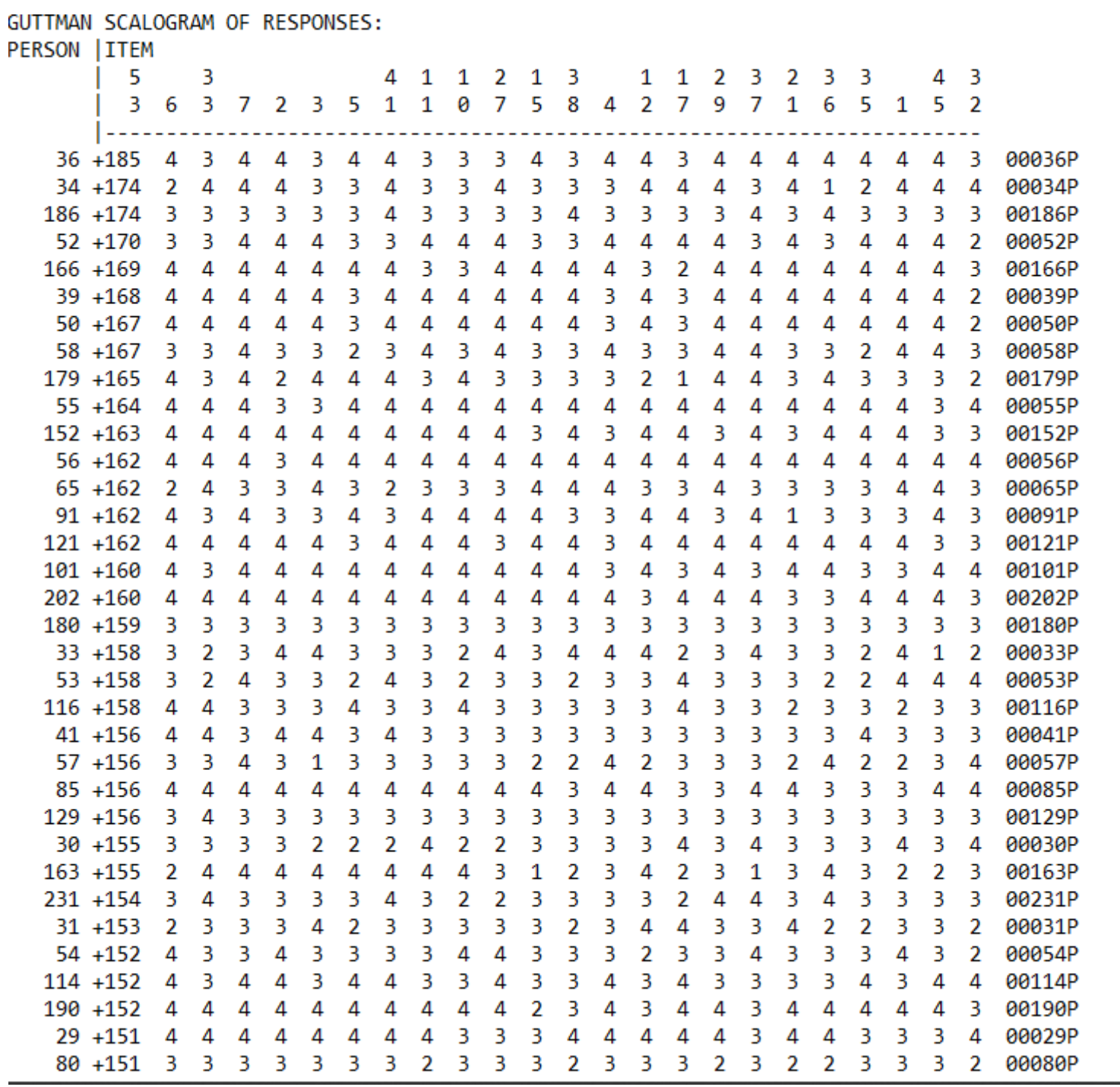

Fig. 3. Scalogram of Self-Concept Engineering Students 
In the scalogram above, it can be seen that students who have the top three self-concept score are respondents number 36. 38 and 184. While students who has the lowest three self-concept score are respondents number 142, 002, and 196.

The scalogram above can be used to identify the respondent's answe $r$, whether they answered consistently or not. In the score pattern obtained by respondents illustrated on the scalogram shows the seriousness of respondents in answering. For example the answer shown by respondent number 036 has a consistent score of 3 and 4 from question number 1 to 52 , so the respondent answers the statement on the scale of self-concept seriously and can certainly not cheat or be influenced by friends, whether in anwering the difficult question or the easy one.

\section{Item Fit}

Some statements are considered difficult or easy by analyzing fit items which validity can be seen in the following figure.

\begin{tabular}{|c|c|c|c|c|c|c|c|c|c|c|c|c|c|}
\hline \multirow{2}{*}{$\begin{array}{l}\text { :NTRY } \\
\text { IUMBER }\end{array}$} & \multirow{2}{*}{$\begin{array}{l}\text { TOTAL } \\
\text { SCORE }\end{array}$} & \multirow{2}{*}{$\begin{array}{l}\text { TOTAL } \\
\text { COUNT }\end{array}$} & \multirow[b]{2}{*}{ MEASURE } & \multirow{2}{*}{$\begin{array}{l}\text { MODEL } \\
\text { S.E. }\end{array}$} & \multicolumn{2}{|c|}{ INFIT } & \multicolumn{2}{|c|}{ OUTFIT } & \multicolumn{2}{|c|}{ |PT-MEASURE } & \multicolumn{2}{|c|}{ EXACT MATCH| } & \multirow[b]{2}{*}{ ITEM } \\
\hline & & & & & MNSQ & ZSTD| & MNSQ & ZSTD & CORR. & EXP.I & OBS\% & EXP\% & \\
\hline & & & & 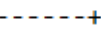 & & ---+ & 年 & ----1 & 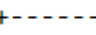 & ----4 & $\cdots$ & ----+ & | \\
\hline 50 & 335 & 232 & 2.30 & $.11 \mid$ & 1.22 & 2.0 & 1.23 & 2.0 & .30 & $.26 \mid$ & 66.8 & 59.5 & VAR00050 \\
\hline 48 & 359 & 232 & 2.04 & $.10 \mid$ & 1.13 & $1.4 \mid$ & 1.11 & 1.1 & .26 & .28 & 52.2 & 52.4 & VAR00048 \\
\hline 20 & 367 & 232 & 1.97 & $.10 \mid$ & .94 & $-.6 \mid$ & .89 & -1.2 & .35 & $.28 \mid$ & 50.0 & 49.5 & VAR00020 \\
\hline 24 & 371 & 232 & 1.93 & $.10 \mid$ & 1.86 & $7.8 \mid$ & 1.69 & 6.2 & .31 & .29 & 50.9 & 48.1 & VAR00024 \\
\hline 26 & 377 & 232 & 1.88 & .09 & .95 & $-.6 \mid$ & .90 & -1.1 & .36 & .29 & 50.0 & $47.1 \mid$ & VAR00026 \\
\hline 19 & 394 & 232 & 1.73 & .09 & .94 & $-.7 \mid$ & .89 & -1.3 & .43 & $.30 \mid$ & 47.8 & 44.5 & VAR00019 \\
\hline 22 & 401 & 232 & 1.67 & .09 & .92 & $-.9 \mid$ & .88 & -1.4 & .45 & $.30 \mid$ & 51.3 & 43.1 & VAR00022 \\
\hline 23 & 407 & 232 & 1.62 & .09 & 1.17 & 2.00 & 1.12 & 1.4 & .37 & .31 & 40.1 & 42.5 & VAR00023 \\
\hline 44 & 407 & 232 & 1.62 & .09 & .95 & $-.6 \mid$ & .95 & -.6 & .40 & .31 & 49.1 & 42.5 & VAR00044 \\
\hline 46 & 416 & 232 & 1.55 & .09 & 1.16 & 1.9 & 1.13 & 1.6 & .20 & .31 & 47.0 & $42.3 \mid$ & VAR00046 \\
\hline 18 & 419 & 232 & 1.53 & .09 & 3.97 & 9.9 & 3.47 & 9.9 & .30 & .31 & 40.9 & $41.7 \mid$ & VAR00018 \\
\hline 16 & 428 & 232 & 1.46 & .09 & 1.31 & $3.6 \mid$ & 1.29 & 3.3 & .29 & .31 & 34.9 & $41.4 \mid$ & VAR00016 \\
\hline 8 & 435 & 232 & 1.41 & .09 & .99 & $-.1 \mid$ & .97 & -.4 & .44 & .32 & 44.8 & $41.4 \mid$ & VAR00008 \\
\hline 25 & 456 & 232 & 1.25 & .08 & .93 & $-.9 \mid$ & .93 & -.9 & .38 & .32 & 45.7 & 41.0 & VAR00025 \\
\hline 14 & 462 & 232 & 1.21 & $.08 \mid$ & 1.17 & $2.1 \mid$ & 1.15 & 1.8 & .37 & .32 & 46.6 & 41.1 & VAR00014 \\
\hline 13 & 481 & 232 & 1.08 & .081 & 1.09 & $1.2 \mid$ & 1.09 & 1.1 & .27 & .33 & 42.2 & $41.8 \mid$ & VAR00013 \\
\hline 28 & 492 & 232 & 1.00 & $.08 \mid$ & 6.20 & $9.9 \mid$ & 6.11 & 9.9 & .24 & $.33 \mid$ & 46.1 & 41.9 & VAR00028 \\
\hline 9 & 495 & 232 & .98 & $.08 \mid$ & 1.02 & $.4 \mid$ & 1.03 & .5 & .32 & $.33 \mid$ & 50.4 & 42.0 & VAR00009 \\
\hline 39 & 534 & 232 & .72 & $.08 \mid$ & .87 & $-1.8 \mid$ & .87 & -1.8 & .37 & $.33 \mid$ & 49.6 & 42.8 & VAR00039 \\
\hline 30 & 544 & 232 & .65 & $.08 \mid$ & 1.01 & $.2 \mid$ & 1.03 & .3 & .34 & $.33 \mid$ & 40.1 & 43.1 & VAR00030 \\
\hline 51 & 546 & 232 & .63 & $.08 \mid$ & 1.14 & 1.7| & 1.15 & 1.8 & .40 & $.33 \mid$ & 45.7 & $43.4 \mid$ & VAR00051 \\
\hline 34 & 563 & 232 & .52 & $.08 \mid$ & 1.18 & 2.2 & 1.19 & 2.2 & .41 & $.33 \mid$ & 37.9 & 43.9 & VAR00034 \\
\hline 52 & 580 & 232 & .40 & $.08 \mid$ & .85 & -1.9 & .86 & -1.8 & .38 & $.33 \mid$ & 45.3 & 44.9 & VAR00052 \\
\hline 43 & 603 & 232 & .24 & .08 & .98 & $-.2 \mid$ & .99 & -.1 & .35 & .32 & 44.4 & 47.0 & VAR00043 \\
\hline 47 & 608 & 232 & .21 & .08 & .70 & -4.0 & .71 & -3.8 & .32 & .32 & 53.0 & 47.5 & VAR00047 \\
\hline 31 & 668 & 232 & -.24 & $.09 \mid$ & 1.02 & $.3 \mid$ & 1.02 & .3 & .14 & .31 & 54.7 & 52.2 & VAR00031 \\
\hline 42 & 703 & 232 & -.52 & $.09 \mid$ & .73 & $-3.2 \mid$ & .75 & -2.9 & .38 & $.30 \mid$ & 59.1 & 52.8 & VAR00042 \\
\hline 40 & 711 & 232 & -.59 & .09 & 1.02 & $.3 \mid$ & 1.09 & .9 & .18 & .29 & 63.8 & $52.7 \mid$ & VAR00040 \\
\hline 49 & 717 & 232 & -.64 & .09 & 1.18 & $1.9 \mid$ & 1.17 & 1.8 & .07 & .29 & 57.3 & 52.5 & VAR00049 \\
\hline 32 & 721 & 232 & -.68 & $.09 \mid$ & 8.96 & 9.9 & 9.90 & 9.9 & .15 & $.29 \mid$ & 48.7 & 52.4 & VAR00032 \\
\hline 45 & 722 & 232 & -.69 & .09 & .73 & $-3.1 \mid$ & .76 & -2.7 & .26 & .29 & 68.1 & $52.3 \mid$ & VAR00045 \\
\hline 1 & 730 & 232 & -.76 & $.10 \mid$ & .73 & -3.0 & .75 & -2.7 & .37 & .29 & 59.9 & $51.9 \mid$ & VAR00001 \\
\hline 35 & 732 & 232 & -.78 & $.10 \mid$ & 8.71 & 9.9 & 9.90 & 9.9 & .21 & $.28 \mid$ & 67.7 & 52.0 & VAR00035 \\
\hline 36 & 735 & 232 & -.81 & $.10 \mid$ & .93 & $-.6 \mid$ & .99 & .0 & .17 & $.28 \mid$ & 56.9 & 52.1 & VAR00036 \\
\hline 21 & 738 & 232 & -.83 & $.10 \mid$ & 8.95 & 9.9 & 9.90 & 9.9 & .18 & $.28 \mid$ & 65.5 & $52.3 \mid$ & VAR00021 \\
\hline 37 & 743 & 232 & -.88 & $.10 \mid$ & .84 & $-1.4 \mid$ & .89 & -.9 & .20 & .28 & 63.4 & $52.4 \mid$ & VAR00037 \\
\hline 29 & 747 & 232 & -.92 & $.10 \mid$ & .75 & -1.9 & .77 & -1.5 & .32 & $.28 \mid$ & 61.2 & $52.4 \mid$ & VAR00029 \\
\hline
\end{tabular}

Fig. 4. Item Measure 
In the figure above shows some items that have been captured, it can be identified with the item norms of discrimination between 0,4 and 0,85 or $0,4<P t$ Measure Corr $>0,85$. To find out whether an item is clear and does not create confusion as well as misconception for the students, Outfit MNSQ $(0,5<\mathrm{MNSQ}>1,5)$ and Outfit ZSTD $(-2,, 0<$

ZSTD > 2,0) should be considered as well as norm on Pt. Measure Corr [10].

Based on that statement, it can be identified that item that can be used and did not cause misconceptions in measuring engineering student's self-concept is item number 34, 14, 23 , $51,08,19,25,22,39$, and 52 .

\section{DISCUSSION}

Self-concept scale reliability has a moderate category of reliability (Fig. 1). This is due to external and internal factors. External factors emerge from used instrument, while internal factors stem from the readiness of the engineering students to work on the self-concept scale. The instrument used have quite a number of items, besides that the quality of the students who work on the self-concept scale doesn't have the same ability, so they will produce different self-concept score as well (Fig. 3).

Another factor that affects the lower reliability is the selfconcept scale has a high level of difficulty items (Fig. 2), while items that can be mantained have a less decent quality of validity (Fig 4). Factor that affect self-concept come from within the individual. One of them is the interpersonal communication skills in expressing identity followed by constructing social contact in social environment [12]. Other than that, factor that influence student's self-concept can also come from experience, especially interpersonal experience, which emits positive feelings and feeling of worth, and competency in respected area by individuals and others [13]. This makes engineering students answers the self-concept scale in accordance with the showed engineering student's self-concept result, which is overall in positive category.

The categorization of positive self-concept students as a whole becomes a component in the item analysis of the selfconcept scale items used. Items are eliminated because the dominant difficulty level is too easy when applied to students of several faculties. Different ability of the constructed items seems to be not quite decent and makes the reliability at a moderate level. The quality of this scale can be said as not optimal yet, because this scale contains almost all items that have a low point measure correlation value. This is according to the opinion that explains, if the value of PT. Measure is greater than 0.4 and less than 0.85 , this instrument is easy to understand and does not cause ambiguity in the subjects [10].

Engineering faculty student's dominant intelligence is on mechanical intelligence, while self-concept is part of intrapersonal intelligence and social intelligence. This allows the results of the analysis per item discussed in figure number 2 which stated about the analysis of engineering students who can answer on the scale of self-concept. Another possibility that is the cause of the results is not balanced with the analysis of items that are considered as other factors or because the quality factor of the measuring instrument is not decent and has been proven in fig. 4 .

Engineering students cannot answer with the standard set as described on the scalogram, because while working, there are some students who lack of concentration in answering, so that this becomes an external factor that afects the results of answers given by students. In addition, the results of these answers are some that are manipulated by students because they have no motivation to answer the scale with too many statements.

These external factors can be referred as lack of concentration and self-confidence in answering items in engineering students. This is in accordance with the results of the study which explains the self-concept of students who are in the low category on the personal dimension of self. In addition, the student's self-concept cannot be measured properly based on the "item map" which is reflected because the ratio of students' ability to answer with difficulty is not directly proportional or balanced.

This becomes the basis the scale of self-concept cannot be generalized because the results are less suitable if applied to engineering students at UNIPA, Surabaya. The selfconcept scale needs to be tested on respondents from other faculties. This becomes an alternative to increase the reliability and validity of the scale of self-concept used. In addition, the scale of self-concept can be tested for external validity so that it can be applied to students in other faculties, because it has a high measure ability of student self-concept.

\section{CONCLUSION}

The conclusion of this study is that all respondents have a positive self-concept. This is indicated by the categorization in the scalogram which shows the respondent's self-concept score dominates in the high category. However, the measuring instruments used were identified as having reliability in the medium category, so the instruments in the form of self-concept scales need to be improved in further. The level of difficulty of the instrument can be seen in Figure 2 which shows items in difficult and easy categories have the same percentage. It can be concluded that the self-concept scale instrument is not suitable for measuring the self-concept of engineering faculty students. This is because the constructed selfconcept scale shows that the quality of the items is inconsistent and the level of reliability is still in the moderate category. The recommendation for further study is that it is necessary to re-examine the respondents for improvement of the instrument and if necessary, testing external validity to the student groups in other faculties. So that the scale of self-concept instruments is accurate when applied.

\section{ACKNOWLEDGMENT}

Authors wishing to acknowledge assistance or encouragement for this study from Prof. Dr. Juntika Nurihsan, M.Pd, and I would say thank you for the UNIPA, Surabaya for its support of my research. Then, I would say thanks to engineering students Universitas PGRI Adi Buana, East Java-Indonesia to their participation in this research. 


\section{REFERENCES}

[1] Findley, D. Self-Concept Clarity and Self-Esteem in Adolescence: Associations with Psychological, Behavioral, and Academic Adjustment, 2013 (January).

[2] Agustiani, H. Psikologi Perkembangan (Pendekatan Ekologi Kaitannya dengan Konsep Diri). Bandung: Refika Aditama, 2006.

[3] Planning, E. Relation of Technology, Science, Self- Concept, Interest , and Gender, 1994 pg. 43-51.

[4] Bharathi, T. A., \& Sreedevi, P. A Study on the Self- Concept of Adolescents, 2016, 5(10), 512-516.

[5] Bharathi, T. A., \& Sreedevi, P. A Study on the Self- Concept of Adolescents, 2018 (April).

[6] Sebastian, C., Burnett, S., \& Blakemore, S. Development of the selfconcept during adolescence, 2008 (October). https://doi.org/10.1016/j.tics.2008.07.008

[7] Ybrandt, H. Self-concept in adolescence. A study of age. UMEA Psychology Reports. Sweden. 2015

[8] Kearney, A. Exclusion from and Within School. Netherlands: Sense Publishers., 2011
[9] Assahhra, M. F. Konsep Diri Remaja yang Tinggal di Panti Asuhan (Studi Kasus). Jurnal Skripsi. Jakarta: Universitas Gunadarma, 2014.

[10] Sumintono, B \& Widhiarso, W. Aplikasi pemodelan RASCH pada assessment pendidikan. Cimahi : Trim Komunikata. 2015

[11] Elisa, M. Skala Konsep Diri. 2012. [online]. Accessed on March 2016 http://elisatjahayoe.blogspot.com/2012/06/skalakonsep-diri.html

[12] Sumintono, B \& Widhiarso, W. (2013). Aplikasi Model Rasch untuk Penelitian Ilmu-Ilmu Sosial. Cimahi : Trimkom Publishing House.2013

[13] Fitts, W. H. The Self Concept and Delinquency. California: Western Psychological Services., 1971 